\title{
BAROKOWI TRUBADURZY CZYLI JAK TŁUMACZYĆ ŚREDNIOWIECZNĄ POEZJĘ OKCYTAŃSKĄ NA JEZYK POLSKI
}

\begin{abstract}
ANNA LOBA
Zainteresowanie francuską literaturą średniowieczną w Polsce zaczyna się od trubadurów. Prace, które powstają - owoc i świadectwo romantycznego uwielbienia dla poezji ludowej i narodowej -, pisali zarówno znani pisarze jak i wykształceni amatorzy. Pierwsze z nich ukazały się bardzo wcześnie, niemal równocześnie z wydaniem przez François-Just Marie Raynouarda jednej z pierwszych francuskich antologii poezji trubadurów ${ }^{1}$. I tak, w 1818 roku ukazuje się esej zatytułowany Rzut oka na wieszczów Prowansji zwanych trubadurami, autorstwa generała Wincentego Krasińskiego, ojca poety ${ }^{2}$. To zainteresowanie poezją okcytańską widoczne jest też w pismach romantyków polskich: Kazimierza Brodzińskiego, Adama Mickiewicza, Józefa Ignacego Kraszewskiego ${ }^{3}$.

Dopiero jednak w drugiej połowie XIX wieku powstają pierwsze próby przekładu tej poezji na język polski. W 1872 roku, podczas odczytu poświęconego trubadurom wygłoszonego w Krakowie i opublikowanego następnie dru-

\footnotetext{
${ }^{1}$ Raynouard, F.-J.M. 1816-1821. Choix des poésies originales des troubadours, t. 1-6. Paris: F. Didot.

${ }^{2}$ Krasiński, W. 1918. Rzut oka na wieszczów Prowancyi zwanych trubadurami. Warszawa: Drukarnia Zawadzkiego i Wedzkiego.

${ }^{3}$ Zob. Romanowiczowa, Z. 1963. „Wstęp”. W: Brewiarz miłości. Antologia liryki staroprowansalskie. Przekład i opracowanie Z. Romanowiczowa. Wrocła: Zakład Narodowy im. Ossolińskic, s. XXVI. Por. też. Kasprzyk, K. 1955. „Literatura staroprowansalska w Polsce”. Kwartalnik Neofilologiczny 2. 110-122.
} 
kiem $^{4}$, Adam Asnyk przedstawia własne przekłady wierszy Jaufré Rudela, Bertranda de Born, Arnauda de Marueil, Ponsa de Capdeuil. Pierwszą antologię poezji trubadurów opracował dla czytelnika polskiego Edward Porębowicz 5 . Zbiór zawiera wiersze dwudziestu siedmiu poetów i kilka utworów anonimowych. Wydanie to, nadal cytowane i do dziś aktualne zostało opublikowane w 1887 roku i było dziełem bardzo młodego tłumacza: przyszły wielki romanista, wybitny tłumacz Dantego miał wówczas dwadzieścia pięć lat i pracował nad swoim doktoratem. Antologię zadedykował swojemu mistrzowi, profesorowi Camille Chabaneau, wydawcy biografii trubadurów. Za Anną Drzewicką należy podkreślić bardzo wczesną datę wydania tej antologii i pionierską rolę jej autora w zapoznawaniu czytelnika polskiego z dziełami trubadurów, wówczas jeszcze w Polsce mało znanych ${ }^{6}$. Niecałe pięćdziesiąt lat później, już pod koniec życia, w latach 30. XX wieku, Porębowicz wydał poprawioną wersję swojej antologii w Wielkiej literaturze powszechnej pod redakcją Stanisława Lama, w której opracował części poświęcone literaturze francuskiej i prowansalskiej ${ }^{7}$.

Mimo że od tego czasu, podejmowane były inne próby przekładów, dopiero w latach 60 . XX wieku ukazały się dwa ważne zbiory poświęcone poezji trubadurów. W 1963 roku poetka i powieściopisarka emigracyjna, Zofia Romanowiczowa wydała w prestiżowej serii Biblioteka Narodowa antologię poezji trubadurów w swoim przekładzie. Tłumaczka, absolwentka Sorbony, z dyplomem z zakresu językoznawstwa prowansalskiego, swoją antologię, zatytułowaną Brewiarz mitości. Antologia liryki staroprowansalskiej, poprzedziła erudycyjnym wstępem i zadedykowała profesorowi Jeanowi Boutière, założycielowi i kierownikowi Instytutu języka i literatury okcytańskiej. Z ogromnego materiału autorka wybrała dwudziestu pięciu poetów i przedstawiła przekłady czterdziestu pięciu utworów, w tym również anonimowych, uzupełniając ten wybór żywotami trubadurów, vidas",

W 1966 roku, trzy lata po tej publikacji, ukazał się pod redakcją Jerzego Lisowskiego pierwszy tom monumentalnej dwujęzycznej antologii poezji francuskiej, która od chwili wydania stała się książką kultową dla co najmniej trzech pokoleń czytelników9 ${ }^{9}$ W pierwszym tomie zatytułowanym: Od Sekwencji

\footnotetext{
${ }^{4}$ Asnyk, A. 1972. Trubadurowie. Odczyt miany w Krakowie. Kraków: „Kraj”.

${ }^{5}$ Porębowicz, E. 1887. Antologia prowansalska. Wybór poezyi trubadurów i felibrów XI-XIX wieku. Warszawa: Teodor Paprocki i S-ka.

${ }^{6}$ Drzewicka, A. 2006. „Literatura starofrancuska na użytek polskich czytelników lat trzydziestych w wersji Edwarda Porębowicza”. W: Wiesiołowski, J. i J. Kowalski. (red.). Wielkopolska. Polska. Europa. Studia dedykowane pamięci Alicji Karłowskiej-Kamzowej. Poznań: Wydawnictwo PTPN. 106.

${ }^{7}$ Porębowicz, E. 1932. Literatura staroprowancka. Warszawa: Trzaska, Ewert i Michalski.

${ }^{8}$ Brewiarz miłości. Antologia liryki staroprowansalskiej, op. cit.

${ }^{9}$ Lisowski, J. 1966. Antologia poezji francuskiej. Tom 1: Od Sekwencji o św. Eulalii do Agrippy d'Aubigné. Warszawa: Czytelnik.
} 
$o$ św. Eulalii do Agrippy d'Aubigné, poezja trubadurów jest szeroko reprezentowana i obejmuje siedemnaście utworów dwunastu poetów okcytańskich. Autor antologii w ten sposób wyjaśnia to honorowe miejsce: „Średniowieczna liryka prowansalska została tu organicznie i chronologicznie wtopiona w dzieje literatury, którą współtworzy i u której żywego źródła czuwa do dziś" ${ }^{10}$. Imponujący projekt ukazania czytelnikowi polskiemu szerokiej panoramy poezji francuskiej zarówno dawnej jak i współczesnej, był też w zamyśle redaktora okazją do przedstawienia przekładów autorstwa najlepszych poetów polskich. Niektóre z nich były specjalnie zamawiane na potrzeby tego wydania. Jednakże jeśli chodzi o trubadurów, Lisowski oparł się na wcześniej już wydanych antologiach Porębowicza i Romanowiczowej. Wyjątkiem jest jeden utwór: Alba Guirauta de Borneil, w tłumaczeniu Jarosława Iwaszkiewicza, które ukazało się wcześniej w jego powieści Czerwone tarcze (1934).

Najnowszą próbą zmierzenia się z przekładem poezji trubadurów jest przedsięwzięcie Jacka Kowalskiego, poety, kompozytora i pieśniarza, a także historyka sztuki, mediewisty, profesora Uniwersytetu im. Adama Mickiewicza. Od 1988 roku wykonuje on swoje własne piosenki oraz dawne pieśni polskie z zespołem „Monogramista JK”. Jego utwory sytuują się na obrzeżach bogatej polskiej tradycji poezji śpiewanej. Karmią się historią, opiewają chwałę i nieszczęścia Rzeczpospolitej. W swoich tekstach Jacek Kowalski posługuje się poetyką pastiszu, miesza rejestry: komizm, patos, gorycz, na wzór dawnej poezji polskiej z XVI i XVII wieku. W 1997 Kowalski stworzył drugi zespół muzyczny: „Klub świętego Ludwika", z którym wykonuje między innymi poezję trubadurów i truwerów oraz fragmenty francuskich średniowiecznych poematów epickich we własnym przekładzie.

Jacek Kowalski jest bowiem nie tylko poetą i piosenkarzem, ale również tłumaczem, specjalistą w zakresie kultury średniowiecznej Francji. To właśnie jego praca naukowa jako mediewisty i historyka sztuki doprowadziła go do literatury francuskiej. Przetłumaczył i wydał poezje Franciszka Villona i poematy Karola Orleańskiego, poprzedzając oba zbiory obszernymi wstępami poświęconymi twórczości obu autorów ${ }^{11}$. Swoje przekłady poezji trubadurów opublikował w dwóch antologiach: Niezbędnik krzyżowca czyli pieśni i opowieści krucjatowe $^{12}$ oraz Niezbędnik trubadura czyli dumania, kancony i romanse ${ }^{13}$. Pierwsza z nich zawiera przekłady nietłumaczonych przedtem na język polski pieśni kru-

${ }^{10}$ Ibidem, 11.

${ }^{11}$ François Villon. 1994. Legaty czyli Maty Testament. Poznań: Studio Bąk. Karol Orleański. 2000. Ronda i ballady. Warszawa: Volumen.

${ }^{12}$ Kowalski, J. 2007. Niezbędnik krzyżowca czyli pieśni $i$ opowieści krucjatowe. (Polski Śpiewnik Historyczny, t. 2). Poznań: Fundacja Świętego Benedykta.

${ }^{13}$ Kowalski, J. 2007. Niezbędnik trubadura czyli dumania, kancony i romanse (Polski Śpiewnik Historyczny, t. 3). Poznań: Fundacja Świętego Benedykta. 
cjatowych, w tym kilku utworów trubadurów: Jaufré Rudela, Marcabru, uzupełnione esejem na temat historii wypraw krzyżowych. Druga antologia to swoiste florilegium, gromadzące między innymi średniowieczne poematy francuskie i okcytańskie z XII i XIII wieku, poprzedzone rzeczowym i wnikliwym wstępem przybliżającym czytelnikowi średniowieczną kulturę i literaturę francuską. Obu antologiom towarzyszą płyty z nagraniami w wykonaniu autora-tłumacza.

Omówiony powyżej ponad stuletni wysiłek przekładowy, mimo rezultatów, których jakość, różnorodność i bogactwo należy docenić, świadczy o tym, że tłumacze poezji trubadurów nadal muszą zmierzyć się z wieloma trudnościami. Przekład dzieł poetyckich francuskiego średniowiecza na język polski okazuje się problematyczny ze względu na nieadekwatność rozwoju kultury polskiej i francuskiej czy okcytańskiej: w XII wieku, kiedy kwitnie twórczość trubadurów, poezja polska jeszcze nie istnieje. Nie można odtworzyć języka polskiego z XI czy z XII wieku, choćby ze względu na to, że pierwsze zdanie języku polskim zapisane w Księdze Henrykowskiej: „Daj ać ja pobruszę a ty poczywaj”, pochodzi dopiero z drugiej połowy XIII wieku. Trudno również mówić o istnieniu polskiego języka literackiego w epoce, w której działali trubadurzy. Stworzenie idiomu zdolnego oddać charakter języka starofrancuskiego albo okcytańskiego pozostaje trudnym do zrealizowania wyzwaniem, któremu muszą stawić czoła wszyscy tłumacze literatury średniowiecznej na język polski, nie tylko poezji trubadurów.

Rozwiązanie, jakie najczęściej wybierają tłumacze polega na stylizacji czy wręcz archaizacji języka. Pytanie, na które muszą sobie odpowiedzieć brzmi: jaki język wybrać, żeby uzyskać pożądany efekt? Językiem najbliższym epoce trubadurów byłby dla polszczyzny język XVI-wieczny, gdyż jest to epoka, w której kiedy rozkwita poezja polska. Aby przełożyć arcydzieło XV-wiecznej literatury francuskiej, Wielki Testament François Villona, Tadeusz Boy-Żeleński zdecydował się naśladować XVI-wieczną polszczyznę, co dało efekt zrazem egzotyczny i anachroniczny, na co zwraca uwagę Anna Drzewicka w artykule poświęconym strategiom, jakie stosują tłumacze literatury dawnej ${ }^{14}$. Przypomina, że jakkolwiek z punktu widzenia chronologicznego i kulturalnego trudno porównać obie epoki, to w perspektywie równie dalekiej, może się wydawać, iż sto czy nawet trzysta lat nie czyni wielkiej różnicy. Na rzecz podobnego anachronizmu można również przedstawiać wspomniane już argumenty o niekompatybilności rozwoju kulturalnego Francji i Polski albo mówić o konieczności

\footnotetext{
${ }^{14}$ Drzewicka, A. 1996. „François Villon i dwóch Franciszków Wilonów”. W: Filipowicz-Rudek, M. i J. Konieczna-Twardzikowa. (red.). Między oryginatem a przekładem, II: Przektad, jego tworzenie się $i$ wptyw. Kraków: Universitas. 49-50.
} 
liczenia się z możliwościami recepcji czytelnika, niezdolnego do zrozumienia średniowiecznej polszczyzny.

Zastosowanie archaizacji w przekładzie dzieł dawnej literatury ma swoich zwolenników i przeciwników ${ }^{15}$. Jak zauważa A. Drzewicka fundamentalny dylemat streszcza się w opozycji: dążyć do uniwersalizmu czy próbować odtworzyć to, co historyczne? Przybliżyć do czytelnika czy przeciwnie - podkreślić dystans? Starać się mówić językiem takim, jakiego używał autor zwracając się do swoich współczesnych, to znaczy: naturalnym i zrozumiałym, czy też usiłować odtworzyć język dawny, jakim autor mówi dzisiaj, po wiekach do swoich współziomków, którzy go z trudnością rozumieją ${ }^{16}$. Inaczej mówiąc czy tłumacz powinien dążyć do tego, by: „nadać piętno dawności, aby wywołać iluzję dystansu czasowego pomiędzy czytelnikiem a tym, co jest przedmiotem lektury" ${ }^{17}$.

Wszyscy polscy tłumacze poezji trubadurów zderzyli się z tymi problemami. Edward Porębowicz i Zofia Romanowiczowa, tłumacze uczeni i wykształceni, specjaliści w swojej dziedzinie, pozostawili przekłady, które pomimo ich piękna i subtelności dają, paradoksalnie, fałszywy obraz poezji okcytańskiej i mogą dziś rozczarowywać. Pewna nieaktualność i anachronizm tych przekładów wypływa z faktu, że noszą one silne znamię wrażliwości romantycznej i postromantycznej. Napisane językiem z XIX i pierwszej połowy XX wieku, językiem który już się nieco zestarzał i pokrył patyną, grzeszą ponadto często nadmiarem sentymentalizmu i afektacji. Aby przekładać poezję trubadurów oboje tłumacze nie odwołują się do szesnastowiecznej polszczyzny, lecz używają języka bardzo starannego, wzniosłego, eleganckiego i często patetycznego. Nagromadzenie słów i wyrażeń, które dziś odbieramy jako rzadko używane, mało znane, niezrozumiałe często stoi w sprzeczności z prostotą przekazu poezji trubadurów. Systematyczne stosowanie zdrobnień (ptaszęta, pątniczkowie, proporczyki), a nawet ich przesadne nagromadzenie powoduje efekt wykwintności, obcy poezji okcytańskiej. Efekt ten zostaje jeszcze bardziej wzmocniony z powodu zamiłowania do skonwencjonalizowanych wyrażeń, zaczerpniętych z poezji romantycznej: ,, skuty w więzy miłości”, „struty jadem miłości”, „los usnuty w kolebce”, „mara miłosna”. Zamiast „rozkwita biały kwiat lilii”, Porębowicz pisze: „białą pierś wygina lilija”, zamiast „napełnia mnie rozkoszą" - „w sercu skrzydła mi rosną”. Oboje tłumacze dorzucają łzy, płacze, rany nawet tam, gdzie ich nie ma. To poezja piękna i elegancka, lecz niemająca wiele wspólnego $\mathrm{z}$ wyrafinowaną

\footnotetext{
${ }^{15}$ Zob. Prokop, J. 1974. „O archaizacji przekładu”. W: Baluch, J. (red.), Z teorii i historii przekładu artystycznego. Kraków: Nakładem Uniwersytetu Jagiellońskiego. 95-100.

${ }^{16}$ Drzewicka, A. „François Villon i dwóch Franciszków Wilonów”, op. cit. 50.

${ }^{17}$ Drzewicka, A. 2012. „De l'ancien français au français moderne. Réflexions sur la traduction intralinguale“. W: Volez ö̈r... “ études sur la littérature française du Moyen Âge. Kraków: Księgarnia Akademicka. 370.
} 
prostotą języka trubadurów. Innym czynnikiem, który może utrudniać kontakt z poezją średniowieczną za pośrednictwem tłumaczeń uznanych za kanoniczne, jest ich staroświecki język. Okazuje się, że przekłady starzeją się szybciej niż można się spodziewać: nawet jeśli dawni tłumacze starali się używać języka współczesnego, z naszego punktu widzenia jest to język, który się już zestarzał, gdyż oddalony jest od nas o ponad sto lat w wypadku Porębowicza i o pięćdziesiąt w wypadku Romanowiczowej.

Przedsięwzięcie Jacka Kowalskiego sytuuje się na przeciwległym biegunie tej tradycji przekładowej. Oryginalność jego przekładów wypływa z faktu, iż czerpią one $\mathrm{z}$ tradycji polskiej poezji preromantycznej, a nawet barokowej, z dziedzictwa XVII i XVIII wieku, bliższej średniowiecznej wrażliwości niż literatura romantyzmu czy modernizmu. Ogromne znaczenie ma fakt, że przekłady Kowalskiego są przeznaczone do śpiewania i rzeczywiście są śpiewane, gdyż tłumacz jest sam wykonawcą swoich wersji pieśni trubadurów. Celem założonego przez niego zespołu: „Klub świętego Ludwika”, jest przywrócenie dawnym utworom ich pełnego wymiaru, tak by dźwięk i słowo dopełniały się wzajemnie. Antologiom przekładów Kowalskiego towarzyszą więc nagrania na płytach CD. Warto dodać, że tłumacz zaprasza do współpracy muzyków związanych z kręgiem muzyki dawnej, a zespół korzysta z rekonstrukcji dawnych instrumentów.

Jakie są kryteria, które decydują o wyborze tekstów do przekładu? W wywiadzie na temat specyfiki tłumaczenia średniowiecznej literatury francuskiej na język polski, Jacek Kowalski udzielił odpowiada, ze wybiera utwory, które go zafascynowały, aby nadać im polską szatę. Najważniejszym kryterium jest możliwość zaprezentowania ich w formie żywej. Dlatego zwraca przede wszystkim uwagę na pieśni, których melodie się zachowały. Dla niektórych sam układa muzykę na średniowieczną modłę ${ }^{18}$. Strategia obrana przez tłumacza, poetę i muzyka w jednej osobie każe mu skonfrontować się z innymi trudnościami, niż te, jakie napotkali jego poprzednicy. Musi znaleźć rozwiązanie problemu, jak pogodzić wierność formie i treści z wiernością wobec melodii, tak, aby wersje polskie zachowały wdzięk i piękno oryginału. Aby osiągnąć ten cel, niektóre teksty są raczej parafrazami niż wiernymi przekładami. Kowalski tłumaczy to w przedmowie do antologii Niezbędnik krzyżowca, pisząc, że jeśli parafrazuje tekst, to postępuje zgodnie z średniowieczną normą, według której tłumacz jest również autorem-poetą. W jego wypadku uciekanie się do parafrazy podykto-

\footnotetext{
18 „Rozmowa o tłumaczeniu średniowiecznej literatury francuskiej (Teresa GiermakZielińska, Joanna Gorecka-Kalita i Jacek Kowalski odpowiadają na pytania Anny Gęsickiej)”. W: Gęsicka, A. (red.). 2010. Królestwo. Świat wartości i antywartości w dawnych literaturach romańskich. Toruń: Wydawnictwo Naukowe Uniwersytetu Mikołaja Kopernika. Litteraria copernicana 2(6). 187.
} 
wane jest tym, że przekłady przeznaczone są od początku do śpiewania i to wykonanie niekiedy współtworzy tekst i narzuca zmiany. Ta potrzeba parafrazowania czasem staje się pokusą parafrazowania, kiedy tłumacz nie może sobie odmówić zastąpienia oryginalnego wyrażenia zwrotem mocniejszym, bardziej obrazowym, uderzającym. Jednak najważniejszą intencją tłumacza jest zachowanie „ducha” poezji trubadurów, nawet ze szkodą dla „litery”"19.

Troska o zachowanie oryginalnej melodii stawia Kowalskiego wobec trudności struktury melodycznej polskiego wiersza: konieczne jest zachowanie rymów męskich, w których akcent pada na ostatnią sylabę, naturalnych w języku francuskim, a odczuwanych jako bardzo sztuczne w języku polskim, zwłaszcza jeśli występują $\mathrm{w}$ większym nagromadzeniu. W polszczyźnie rym męski możliwy jest w wypadku słów jednosylabowych, których wybór jest dość ograniczony. Tłumacz zachowuje więc oryginalne rymy tylko tam, gdzie to jest absolutnie konieczne, w innych wypadkach zastępuje je rymami żeńskimi, naturalnymi dla języka polskiego, jeśli dają się pogodzić z melodią. W strategii tłumaczeniowej Kowalskiego muzyka odgrywa więc nadrzędną rolę.

Inny problem jest związany z typową dla utworów prowansalskich formą strofy, opartej na dwu, wielokrotnie powtarzanych rymach. W poezji polskiej podobna powtarzalność jest uznawana za nudną i nużącą dla ucha, dlatego zabieg ten jest trudny do przetłumaczenia. Kowalski wyjaśnia, że zachowuje jednolite rymy tylko tam, gdzie uznaje to za absolutnie konieczne lub chociażby możliwe. Za przykład może posłużyć dokonany przez tego tłumacza pierwszy polski przekład jednej z najpiękniejszych i najbardziej tragicznych pieśni liryki okcytańskiej: „Quan vei la lauseta mover” Bernarda de Ventadour. Aby można było śpiewać tekst, należało posłużyć się wyłącznie rymem męskim i tak nim operować, aby przekład nie wydawał się ani sztuczny ani prymitywny. Tymczasem pieśń tego trubadura jest prawdziwą skarbnicą obrazów, które dziś stały się banalne, a w epoce, kiedy powstały były świeże i żywe. Wyzwaniem dla tłumacza i wykonawcy w jednej osobie stało się opracowanie takiego przekładu, który zachowałby całe muzyczne wyrafinowanie oryginału, a jednocześnie nie ocierałby się o banał i oddał piękno oryginału, stworzenie ,pieśni prostej i dobitnej, skondensowanej, porywającej, pozbawionej czułostkowości"20.

Aby osiągnąć ten ideał - i tu dochodzimy do tego, co stanowi o oryginalności i sukcesie tych przekładów - Jacek Kowalski wybiera język i obrazy zaczerpnięte z polskiego baroku. Poeta i tłumacz jest wrażliwy na barokowe upodobanie do kontrastów, opozycji, skrajności: ciało w jego przekładach przeciwstawia się duszy, miłość - wojnie, Bóg - materii. Te kontrasty, które charak-

\footnotetext{
${ }^{19}$ Kowalski, J. Niezbędnik krzyżowca, op. cit.

${ }^{20}$ Kowalski, J. „Bernard de Ventadour, Quan vei la lauseta mover”. W: Królestwo. Świat wartości i antywartości $w$ dawnych literaturach romańskich, op. cit. 191.
} 
teryzują polską poezję barokową można odnaleźć również w poezji trubadurów. Dawne przekłady złagodziły skrajności i ostudziły żarliwą, namiętną wrażliwość trubadurów, gdyż postromantyczni tłumacze wybierali retorykę bardziej intymistyczną, co w rezultacie dawało często efekt zbyt cukierkowy, naiwny i sentymentalny. Tymczasem, poprzez odwołanie się do barokowego anachronizmu, Kowalski wydobywa napięcia i emocje charakterystyczne dla poezji trubadurów, podkreślając je aż do przesady. Tłumacz ten nie boi się kontrastów: dla niego pomieszanie komizmu, rubaszności, burleski z patetyzmem i wzniosłością nie stanowi żadnego problemu. Okazuje się, że poezja trubadurów komponuje się doskonale z pieśniami staropolskimi, poezją polskich poetów barokowych, którzy tak jak trubadurzy potrafili godzić skrajne namiętności.

Trzeba więc było podążyć okrężną drogą przez poezję barokową, sarmacką, żeby liryka trubadurów stała się bliska współczesnemu odbiorcy dzięki odwołaniu się do polskiej historii i literatury. Ta strategia zbliżenia dokonuje się również poprzez język: między czytelnikiem a tekstem nie ma żadnej bariery. Nawet jeśli Kowalski odwołuje się do archaizmów, zawsze dostosowuje swój przekład do możliwości recepcji czytelnika ${ }^{21}$. Okazjonalna archaizacja staje się dyskretnym znakiem, a nie systematyczną rekonstrukcją dawnego języka. Książki, płyty i koncerty Jacka Kowalskiego czynią z tego połączenia tradycji swój znak markowy. Można zarzucać tłumaczowi pewną niespójność, brak konsekwencji tam, gdzie w tekście pozornie współczesnym czytelnik napotyka od czasu do czasu formę, słowo, konstrukcję, które odbiegają od naszych przyzwyczajeń i wprowadzają pewien zgrzyt. Można mu zarzucić eklektyzm, pewną dezynwolturę, z jaką każe prowadzić dialog tekstom z różnych epok. Lecz jego strategia okazuje się skuteczna: jego przekłady są dużo bardziej zrozumiałe i łatwiejsze w odbiorze niż dawne.

Trudno byłoby negować poetycką wartość przekładów Jacka Kowalskiego. Trzeba podziwiać wysiłek włożony w poszukiwanie ekwiwalencji stylistycznej, melodycznej i leksykalnej. Strategia antyromantyczna i barokowa, ale również anachroniczna i archaiczna jego przekładów i interpretacji pozwoliła prowansalskim trubadurom zachować w języku polskim zarazem ich inność i ich aktualność.

\footnotetext{
${ }^{21}$ Warto zauważyć, że strategię tę J. Kowalski stosuje nie tylko w wypadku przekładów poezji trubadurów, lecz charakteryzuje ona również inne jego przekłady literatury średniowiecznej. Por. Drzewicka, A. „François Villon i dwóch Franciszków Wilonów”, op. cit. 55.
} 